\title{
模擬トリーチャンネルからのトリー伸展現象と部分放電特性
}

学生員 河端 宏樹* 学生員 金 忠植*
正 員 水谷 照吉*

\section{Tree Propagation from an Artificially-Simulated Tree Channel and Characteristics of Partial Discharge}

Hiroki Kawabata*, Student Member, Choong-Sik Kim*, Student Member, Teruyoshi Mizutani*, Member

In order to clarify the mechanisms of partial discharge (PD) and tree degradation, PD characteristics of an artificially-simulated tree channel in low-density polyethylene (LDPE) were investigated. During the application of AC voltage, new tree channels were formed at the tip of the artificial channel. PD characteristics of an artificial channel with $2 \mathrm{~mm}$ in length and $30 \mu \mathrm{m}$ in diameter remarkably changed after the inception of very small trees. After the tree inception, the number of PD pulses increased and light emission due to PD extended to a whole channel and new tree channel. A few minutes after the tree inception, the number of negative PD pulses decreased and its magnitude became large. These results suggest the change in PD mechanism by tree inception and tree propagation. From these results, the mechanisms of PD in a tree channel and tree propagation were discussed. These results are applicable to insulation diagnosis.

キーワード : 電気トリー, 部分放電 $(\mathrm{PD})$, 模擬トリーチャンネル, PD $\phi^{-} \mathrm{q}-\mathrm{n}$ パターン, PD パルス時系列分布

Keywords : electrical tree, partial discharge (PD), artificially-simulated tree channel, PD $\phi^{-} \mathrm{q}^{-n}$ pattern, PD pulse sequence

\section{1. はじめに}

固体高分子絶縁材料における電気トリーイング現象は, 最終的に絶縁破壊に至ることから, 重要な劣化現象の一つ である。電気トリーは部分放電 (PD) 現象を伴うことから, $\mathrm{PD}$ の検出による電気トリー劣化の診断が有効であると指 摘されており, 主に PD の統計的性格や $\phi-q-n$ (位相角一電 荷量一発生頻度）分布などに着目して研究が進められてき た(1) (3)。一般に PD 現象を電気トリー劣化の診断に応用す る場合, その機構を解明することは診断精度の向上に重要 な意味を持つ。

しかしながら, 実際の電気トリーは多数のチャンネルが 複雑に組み合わされた構造となっており, トリー内で発生 する PD も多数の放電路で起こっている。そのため, 電気卜 リーにおいて検出された PD がどのチャンネルにおいて発 生したものかを特定するのは極めて難しく, 電気トリ一内 で発生する PD 現象は非常に複雑であると考えられる。

電気卜リーに伴う PD の特性を解明するため, 電気トリー

\footnotetext{
名古屋大学大学院工学研究科電気工学専攻

T464-8603 名古屋市千種区不老町

Department of Electrical Engineering, Graduate School of Engineering, Nagoya University

Furo-cho, Chikusa-ku, Nagoya 464-8603
}

の一本のチャンネルを模擬した人工チャンネル（模擬トリ 一チャンネル）を絶縁体中に作製し，模擬トリーチャンネ

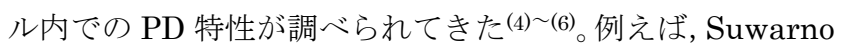
らは放電の位相角解析を行い, $\mathrm{PD}$ パターンや PD パルス時 系列分布から直径 $40 \mu \mathrm{m}$ 以下のチャンネルでの放電特性が 実際の電気トリーの放電特性に近いことを示し, トリ一内 の PD を模擬トリーチャンネルにより模擬できる可能性を 指摘した ${ }^{(7)}$ 。また, 金岩らは直径 $10 \mu \mathrm{m}$ の模擬トリーチャ ンネルを用いて, チャンネル内で発生する PD 特性を $\mathrm{PD}$ パ ルスの測定から調べ，模擬トリーチャンネルでの放電特性 の一部を明らかにし(8), さらに模擬トリーチャンネルの先端 から新たにトリーが発生する前後では PD の特性が変化す ることを明らかにした (9)。しかしながら, トリー伸展前後で の PD 特性の変化については不明な点が多く, トリー伸展機 構および PD 機構との関連については明らかになっていな い。

そこで筆者らは，模擬トリーチャンネル先端からトリー が伸展する前後の PD 特性の変化に着目し, PD パルスの時 系列分布の測定および PDによる発光の観測を行い, トリー の発生や伸展が PD 特性に及ぼす影響についての検討を行 った。 


\section{2. 試料および実験方法}

〈2・1〉 試料試料形状を図 1 に示す。試料作製は以 下の手順で行った。まず, 針電極として用いるタングステ ン線（直径 $30 \mu \mathrm{m} ）$ の先端を電解研磨法によって先端曲率 半径を約 $3 \mu \mathrm{m}$ とし, 厚さ $4 \mathrm{~mm}$ の低密度ポリエチレン

(LDPE) ブロックに挿入後, ホットプレス（温度 $110{ }^{\circ} \mathrm{C}$, 圧力 $200 \mathrm{~kg} / \mathrm{cm}^{2}, 5$ 分）を行った。その後, タングステン

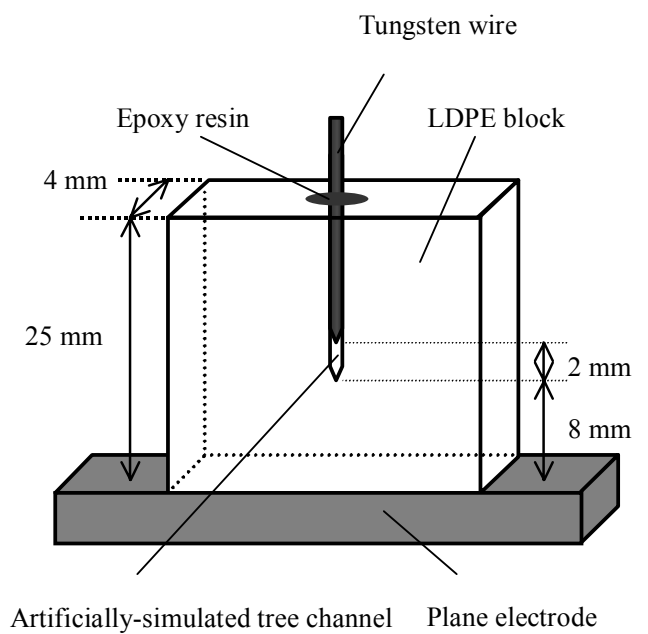

図 1 試料形状

Fig. 1. Sample configuration.

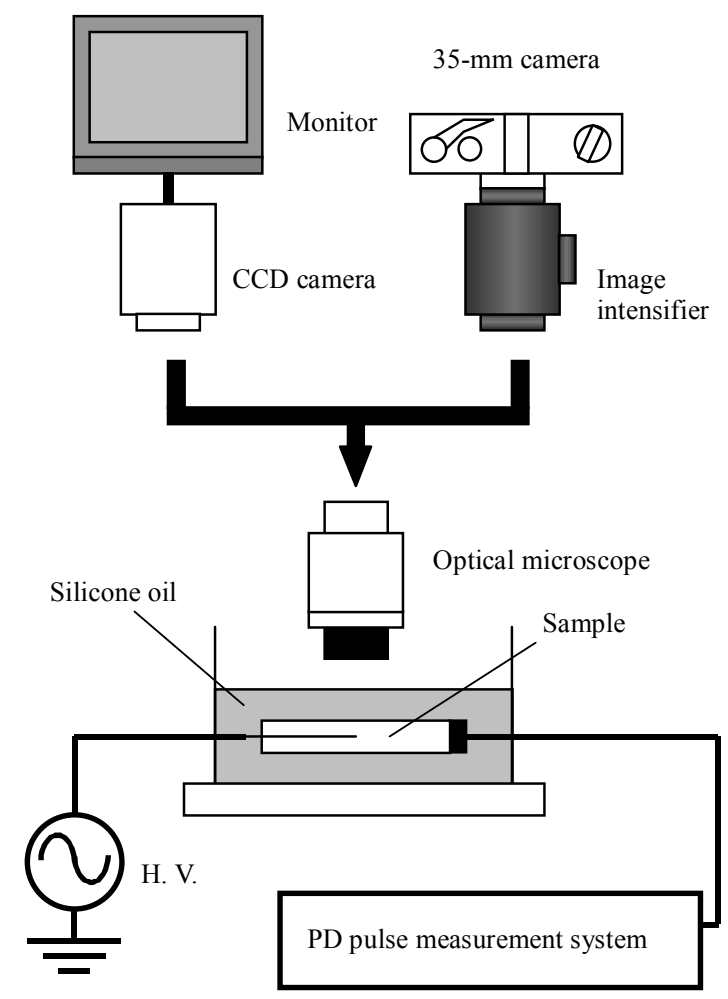

図 2 PD 計測およびトリー観測システムの概略

Fig. 2. PD-measurement and tree-observation system.
線を $2 \mathrm{~mm}$ 引き抜き, 模擬トリーチャンネル（直径 $30 \mu \mathrm{m}$, 長さ $2 \mathrm{~mm}$ ）を作製した。試料は電極間隔が $10 \mathrm{~mm}$ の針一 平板電極構造とし, 実験中にチャンネル内のガスが逃げな いようにタングステン線挿入口部分をエポキシ樹脂でふさ いだ。

〈2·2〉実験方法ＰD 計測およびトリー観測システ ムを図 2 に示す。試料をシリコーン油中に浸し, 針電極で あるタングステン線に周波数 $60 \mathrm{~Hz}$ の交流電圧を印加して, 模擬トリーチャンネル中で発生する PD を測定した。印加電 圧は $4 \mathrm{kVrms}$ とし, 電圧印加後 20 分後に $6 \mathrm{kVrms}$ に上昇 させた。PDの測定には, コンピューターを用いた部分放電 パルス計測装置(10)を用いた。測定時間を 10 秒間（600 サイ クル）とし，この間に発生した PDを用いて PD $\phi-q-n$ パタ ーンを構築した。PD の計測と同時に, 光学顕微鏡および $\mathrm{CCD}$ カメラを用いて, 模擬トリーチャンネルの形状の観測 を行った。また, 光学顕微鏡, イメージインテンシファイ アおよび $35 \mathrm{~mm}$ 一眼レフカメラを用いて, 発光の観測も行 った。

\section{3. 実験結果}

〈3·1〉 トリー発生前後の部分放電特性 図 3 に印加 電圧を示す。試料に, $4 \mathrm{kV}$ の電圧を 20 分間印加しても, 模擬卜リーチャンネル先端からの新たなトリーの発生は見 られなかった。そこで, 印加電圧を $6 \mathrm{kV}$ に上昇させたとこ ろ, 6 分後 (電圧印加後 26 分後) に, 模擬卜リーチャンネ ル先端から新たなトリーの発生が見られた。また，トリー 発生から 3 分後には, PD 特性が大きく変化した。本論文で は, 印加電圧 $4 \mathrm{kV}$ である電圧印加後 0〜20 分後を Stage 1, 印加電圧 $6 \mathrm{kV}$ でトリー発生までの電圧印加後 20〜26 分後 を Stage 2 , トリー発生後の電圧印加後 $26 \sim 29$ 分後を Stage 3 , 電圧印加後 $29 \sim 50$ 分後を Stage 4 と呼ぶこととする。

図 4 にトリー形状を示す。模擬卜リーチャンネル先端か ら発生したトリーは時間とともに成長し, チャンネル数の 増加とともにトリーの密度は高くなった。トリー発生から 10 分後にはトリーの長さは $100 \mu \mathrm{m}$ 程度に達した。

図 5 に各 Stage における PD $\phi^{-} \mathrm{q}$-n パターンを示す。トリ 一発生前である Stage 1 および Stage 2 においては, 電気卜

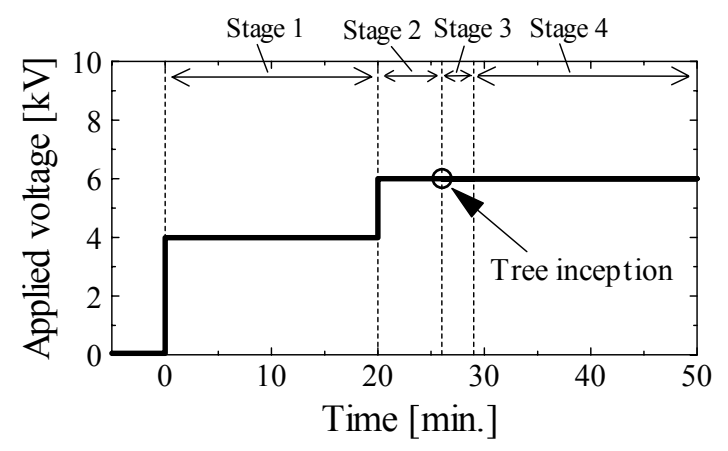

図 3 印加電圧

Fig. 3. Applied voltage. 


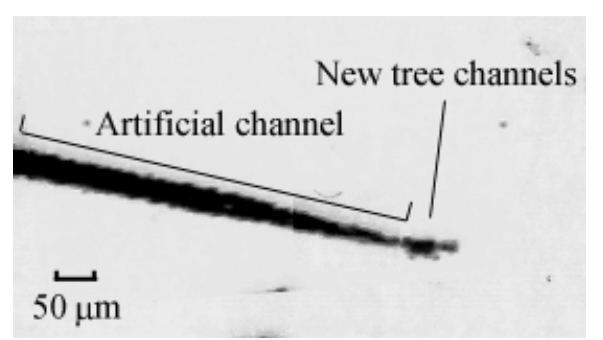

(a) トリー発生後 3 分後

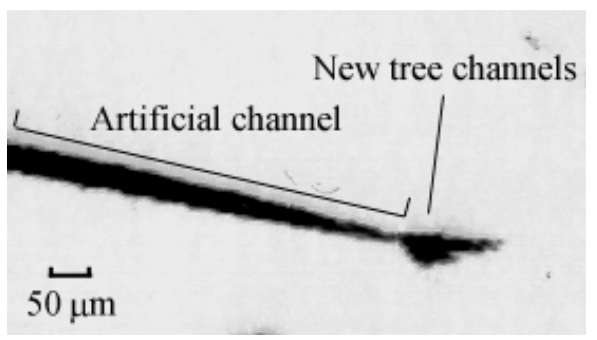

(b) トリー発生後 10 分後

図 4 トリー形状

Fig. 4. Tree shape.

リーで見られるような羽型パターン(3)を示している。特に負 極性側（位相 90〜270 度）で顕著である。トリー発生後の Stage 3 では, 電荷量の小さな放電が多くなっている。特に 負極性においては，トリー発生前に見られたようなー 100 $\mathrm{pC}$ 前後の大きな電荷量をもった放電は見られない。Stage 4 では, 電荷量の大きな放電が見られ, 最大放電電荷量が正

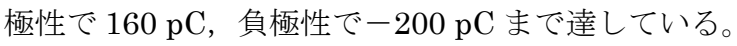

図 6 に, 各 Stage における PD パルス時系列分布を示す。 Stage 1 では半サイクルあたり 3〜 5 発程度, Stage 2 では 半サイクルあたり $7 \sim 8$ 発程度の放電が発生している。 Stage 3 では電荷量が $100 \mathrm{pC}$ 以下の小さな放電が半サイク ルあたり 10〜12 発程度発生し, Stage 4 では正極性で半サ イクルあたり 7〜 8 発程度の放電が発生し, 負極性では電荷 量が-150 pC 程度の大きな放電が半サイクルあたり $1 \sim 3$ 発程度発生している。

図 7 に, 1 サイクルあたりの PD パルス数の経時変化を示 す。電圧を上昇させた Stage 2 でパルス数は増加し，さらに 模擬トリーチャンネル先端からのトリー発生に伴い，パル 又数は急増するが，その後減少し，やがて一定值に達する。

このように，模擬卜リーチャンネル先端からのトリー発 生・伸展によって, PD 特性が変化することがわかる。

〈3·2〉模擬トリーチャンネル内での発光 図 8 に, 各 Stage における模擬トリーチャンネル内での発光像を示 す。ここで, 発光像は 10 秒間にわたる正負両極性での複数 のパルスによる発光の蓄積画像である。

印加電圧が $4 \mathrm{kV}$ である Stage 1 では, 発光は模擬トリー チャンネルの針電極側で強く観測され，発光はチャンネル 先端まで達していない（図 $8(\mathrm{a})$ )。印加電圧を $6 \mathrm{kV}$ に上昇 させた Stage 2 では, 発光は模擬トリーチャンネ先端まで達

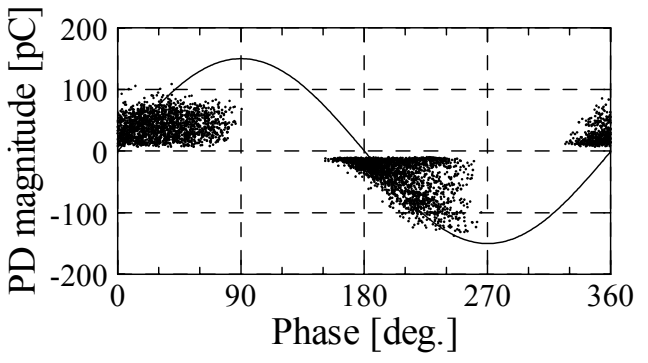

(a) Stage 1 (電圧印加後 13 分後)

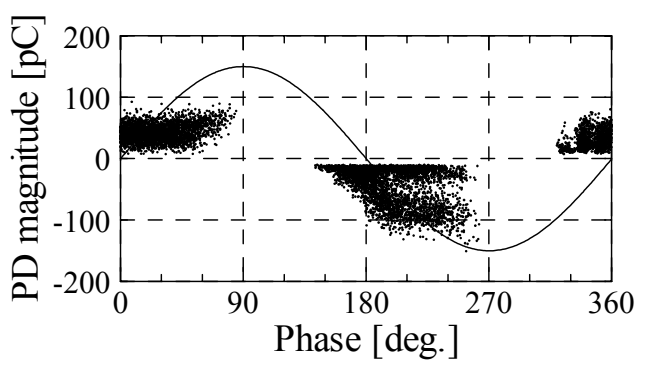

(b) Stage 2 (電圧印加後 22 分後）

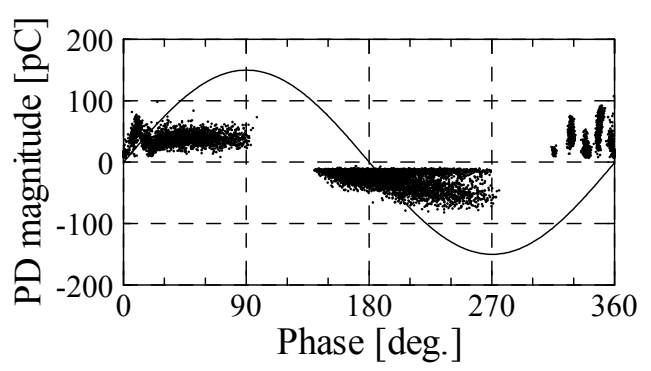

(c) Stage 3 (電圧印加後 28 分後)

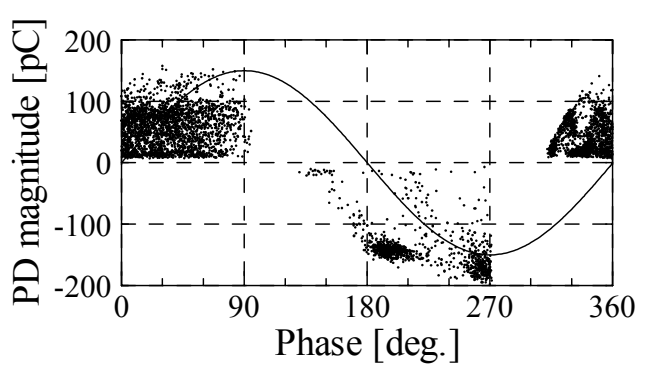

(d) Stage 4（電圧印加後 38 分後）

図 5 PD $\phi-\mathrm{q}-\mathrm{n}$ パターン

Fig.5. PD $\phi^{-} q^{-n}$ pattern.

し, チャンネル全体に広がっている（図 $8(\mathrm{~b}))$ 。発光強度は Stage 1 と同様に針電極先端付近が強い。トリ一発生後の Stage 3 および Stage 4 では, 発光領域は模擬トリーチャン ネル全体に加えてチャンネル先端から新たに発生したトリ 一チャンネルでも観測された。

このように, 発光が模擬トリーチャンネル先端に達する と, やがてそこから新たなトリーが発生し, 放電発光領域 が変化することがわかる。 


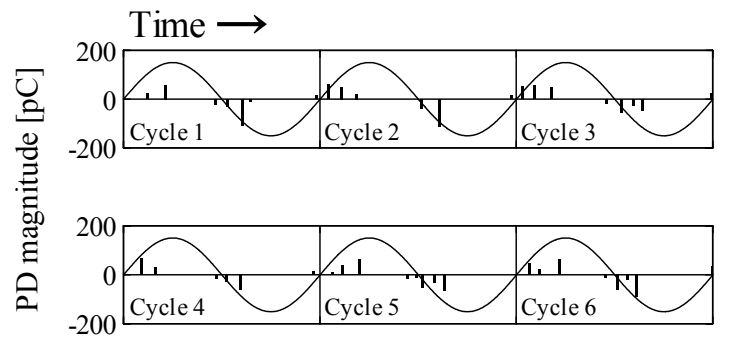

(a) Stage 1 (電圧印加後 13 分後)

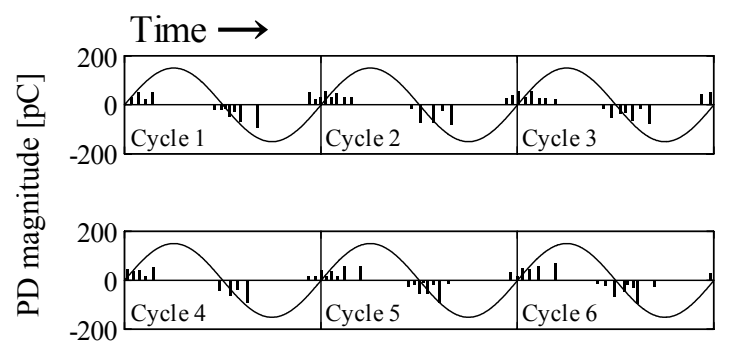

(b) Stage 2 (電圧印加後 22 分後)

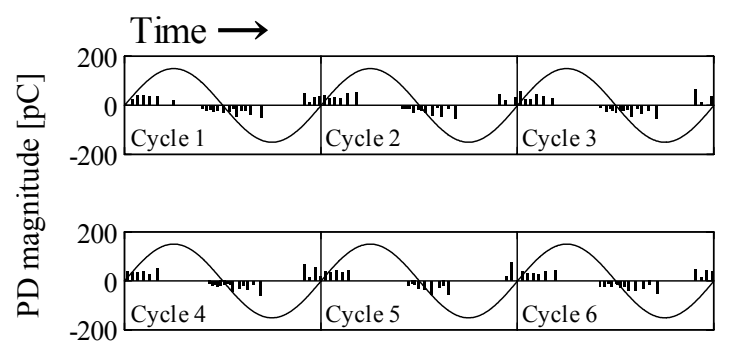

(c) Stage 3 (電圧印加後 28 分後)

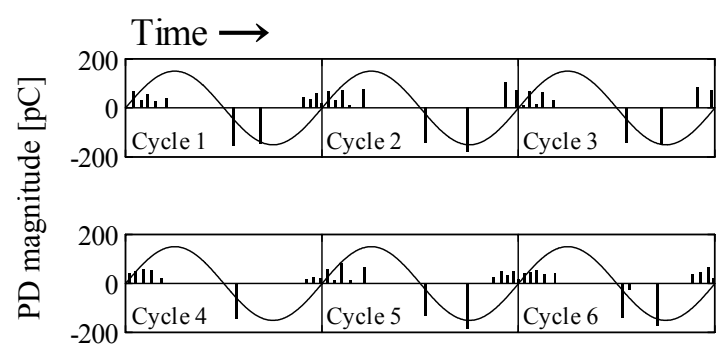

(d) Stage 4 (電圧印加後 38 分後)

図 $6 \mathrm{PD}$ パルス時系列分布

Fig. 6. PD pulse sequence.

\section{4. 検討}

〈4·1〉 トリー発生前の PD 機構 Stage 1 の発光は模 擬トリーチャンネルの針電極側で観測され，発光強度は針 電極先端付近が強いことから，模擬トリーチャンネル内の 放電は針電極先端から開始してチャンネル途中で停止する と考えられる。Stage 2 では発光領域は模擬トリーチャンネ ル全体に広がっている。これは，電圧を上昇させたことで 針電極先端から開始した放電がチャンネル先端付近まで到 達したためであると言える。金岩らは，トリー発生前の模

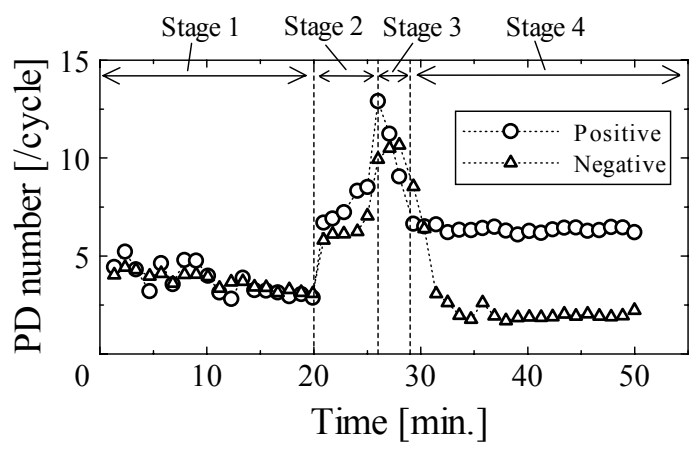

図 7 1 サイクルあたりの PD パルス数

Fig. 7. PD pulse number per cycle.

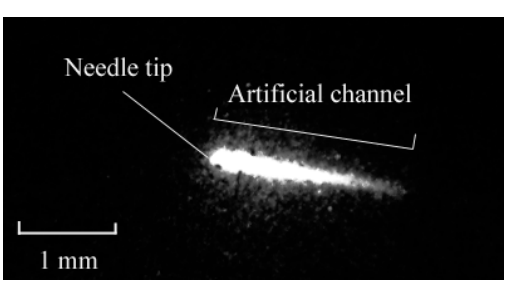

(a) Stage 1 （電圧印加後 13 分後）

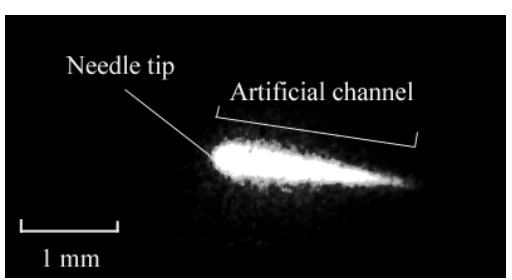

(b) Stage 2（電圧印加後 22 分後）

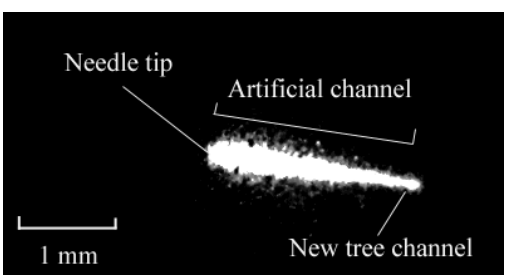

(c) Stage 3 (電圧印加後 28 分後)

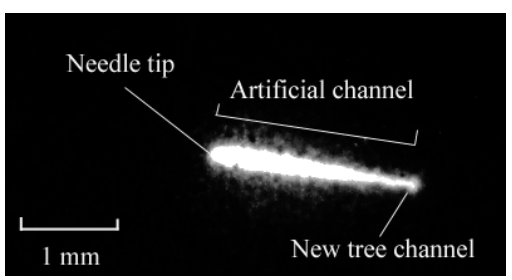

(d) Stage 4 （電圧印加後 38 分後）

図 8 発光像

Fig. 8. Image of light emission.

擬トリーチャンネルでは, PD 発光領域がチャンネル先端ま で到達するようになると, やがてチャンネル先端から電気 トリーが発生することを報告しており(11)，模擬卜リーチャ ンネル中の放電がチャンネル先端にダメージを与えトリー 発生を引き起こすと推測される。 
トリー発生前の模擬トリーチャンネルでは, 正極性 PD よ りも負極性 PD のほうが最大放電電荷量は大きい。一般に, 細管中での放電路の長さとともに放電電荷量が増加すると 考えると, 正極性 PD よりも負極性 PD のほうがチャンネル 先端まで伸びていると考えられる。正極性 PD では, 放電は 針電極付近の自由電子による衝突電離（なだれ）で開始し， 電子に比べて移動度の小さい正電荷がなだれの後方に残さ れる。この正電荷による電界強調により, チャンネル先端 方向に新たな電子なだれを発生させて, 放電が伸展すると 報告されている。これに対して, 負極性 PD では針電極から 注入された電子によって電子なだれが開始し, チャンネル 先端へ伸展する。移動度の大きい電子が細管中を伸展する ので, 大気中の放電と異なり放電先端の電界緩和も小さく, 負極性 PDの伸展が正極性 PDに比べて伸びやすいことは理 解できる。

このようなモデルを考えると, チャンネル先端付近にま で到達するような大きな電荷量をもった負極性 PD によっ てチャンネル先端にダメージが蓄積し, 電気トリーの発生 に至ったものと考えられる。チャンネル先端におよぼすダ メージとしては, 放電がチャンネル先端に到達することに よって生じるチャンネル先端での局所的な高電界の形成, 放電電荷の衝突によるポリエチレンの分子鎖切断や温度上 昇などが考えられる。

\section{$\langle 4 \cdot 2\rangle \quad$ トリ一発生前後の PD 特性の変化 $\quad$ トリー発} 生前の Stage 2 では, 放電発光領域は模擬トリーチャンネル 全体に広がっているが, チャンネル先端付近の発光強度は 弱い。これに対して, トリー発生後の Stage 3 では, チャン ネル先端付近の発光強度も強くなり, さらに新たに発生し たトリー部でも発光が観測される。また，負極性において は，トリー発生前で見られたような大きな電荷量をもった 放電は見られない。細管中での放電電荷量は放電の長さと ともに増加すると考えられるが，放電電荷量の減少にも関 わらず模擬トリーチャンネル全体で発光が観測されてい る。このことから, Stage 2 と Stage 3 では放電の状況が変 化していることが示唆される。このことは, 図 7 に示すよ うに, 模擬トリーチャンネル先端からの微小トリー発生と 同時に, 放電パルス数が急増することからも推測される。

一般に, 電気トリー内での部分放電の発生は, トリー周 辺に存在する空間電荷によって影響を受けることが報告さ れている。例えば，交流トリー初期での負パルスの欠陥は， チャンネル先端付近の負の空間電荷による電界緩和により 説明されている(12)。トリー発生前の模擬トリーチャンネル においては, 前節で述べたように負極性 PD がチャンネル先 端に到達し, チャンネル先端に電荷が移動し, 放電が停止 する。トリー発生後は, 新たに発生した微小トリー部で局 所電界の集中が生じ, ここから放電が開始し，模擬卜リー チャンネル部の放電を活発にすることが考えられる。この ため模擬トリーチャンネル内の放電が生じやすくなり, 放 電パルス数が増え, 放電電荷量が小さくなったものと推測 される。放電の変化にはチャンネル内のガス圧の変化も考
えられるが, チャンネル内のガス圧の測定は行っていない ので，この点についての検討はここでは割愛する。長さ 2 $\mathrm{mm}$ の模擬トリーチャンネルの先端に長さ $100 \mu \mathrm{m}$ 程度の 微小トリーが形成されたことによる急激なガス圧の変化は ほとんどないものと推測している。

〈4·3〉 トリー伸展中のPD 特性の変化 Stage 3 およ び Stage 4 では, いずれも発光は模擬トリーチャンネル全体 および新たに発生したトリー部で観測され, 発光領域には 大きな変化は認められない。しかし, トリー発生後しばら くすると (Stage 4), 正極性, 負極性ともに, トリー発生前 よりも大きな電荷量をもった放電が観測されるようにな る。顕微鏡観察から, 発生したトリーの密度が高くなって いることが確認されるので, これによりトリー先端部の局 所電界の強調が抑えられ, 放電パルス数は減少し, 放電電 荷量は大きくなるものと推測される。

このように, トリー伸展中における $\mathrm{PD}$ 特性の変化は, ト リーが成長することでトリー形状が変化したためであると 結論される。

\section{5. むすび}

本論文では, 低密度ポリエチレン中に電気トリーの一本 のチャンネルを模擬した人工チャンネル（模擬トリーチャ ンネル）を作製し, 模擬トリーチャンネル内での PD 特性を 調べた。模擬トリーチャンネル先端からのトリー伸展前後 での PD 特性の変化に着目し, PD パルスの時系列分布の測 定および PDによる発光の観測を行い, トリーの発生や伸展 が PD 特性に及ぼす影響についての検討を行った。本論文で 得られた結果をまとめると以下のようになる。

（1）模擬トリーチャンネル先端から電気トリーが発生す るには, チャンネル先端に放電が到達する必要がある。

（2）模擬トリーチャンネルからの電気トリー発生によっ て, PD 特性は変化する。トリー発生後は放電パルス数が増 加し, 負極性においては放電電荷量が小さくなる。また, 放電発光領域は模擬トリーチャンネル全体および新たに発 生したトリー部に広がる。

（3）電気トリ一伸展によって, PD 特性は変化する。放電 パルス数は減少し, 放電電荷量は増加する。このことは, チャンネル先端のトリー形状の変化と対応している。

(平成 14 年 6 月 26 日受付, 平成 14 年 10 月 4 日再受付)

\section{文献}

(1) C. Laurent and C. Mayoux : "Analysis of the Propagation of Electrical Treeing Using Optical and Electrical Methods", IEEE Trans. EI, Vol.15, No. 1, pp. 33-42 (1980-2)

(2) N. Nishiguchi, F. Komori, M. Hikita, and T. Mizutani : "Detection of Electrical Tree Initiation and Assessment of Shape of the Developing Tree Using Pattern Recognition of Partial Discharge Occurrence Phase Distribution", T. IEE Japan, Vol. 113-A, No. 7, pp. 527-534 (1993-7) (in Japanese)

西口法明・古森郁尊・匹田政幸・水谷照吉：「部分放電発生位相角分 布パターンの認識による電気トリーの有無および形状の判定」, 電学 論 A， 113， 7, pp. 527-534 (1993-7) 
(3) Suwarno, Y. Suzuoki, T. Mizutani, and K. Uchida : "Partial Discharge Pattern Changes due to Electrical Tree Growth in Polyethylene", T. IEE Japan, Vol. 115-A, No. 11, pp. 1121-1129 (1995-11) (in Japanese)

Suwarno・鈴置保雄・水谷照吉・内田克己：「ポリエチレン中の電気 トリーの進展に伴う $\mathrm{PD}$ パターンの変化」, 電学論 $\mathrm{A}, 115,11, \mathrm{pp}$. 1121-1129 (1995-11)

(4) A. B. Borishade : "The Development of Electrical Discharges in Simulated "Tree" Channels", IEEE Trans. EI, Vol.12, No. 5, pp.348-354 (1977-10)

(5) W. Y. Gu, C. Laurent, and C. Mayoux : "Characteristics of Discharges inside Simulated Tree Channels under Impulse Voltage", J. Phys. D: Appl. Phys., Vol.19, pp. 2197-2207 (1986-11)

(6) D. W. Auckland, S. M. F. Kabir, and B. R. Varlow : "Charge Deposition in Gas Filled Channels with Insulating Walls", IEE Proc. A, Vol.140, No. 6, pp. 509-516 (1993-11)

(7) Suwarno, Y. Suzuoki, and T. Mizutani : "Phase-Resolved Measurement of Partial Discharge in Artificially-Simulated Tree Channel", Proc. of 5th Int. Conf. on Prop. \& Appl. of Dielect. Mats., pp. 267-270 (1997-5)

(8) H. Kaneiwa, Y. Suzuoki, and T. Mizutani : "Characteristics of Partial Discharge Pulse Trains in an Artificially-Simulated Tree Channel in Solid Insulating Material", T. IEE Japan, Vol. 119-A, No. 7, pp. 1051-1058 (1999-7) (in Japanese)

金岩浩志・鈴置保雄・水谷照吉 : 「固体絶縁体中の模擬卜リーチャン ネルにおける部分放電パルス列の特性」, 電学論 $\mathrm{A}, 119,7, \mathrm{pp}$. 1051-1058 (1999-7)

(9) H. Kaneiwa, Y. Suzuoki, and T. Mizutani : "Characteristics of Partial Discharge Pulse Trains under Tree Propagation from an Artificially-Simulated Tree Channel", T. IEE Japan, Vol. 120-A, No. 4, pp. 499-505 (2000-4) (in Japanese)

金岩浩志・鈴置保雄・水谷照吉 : 「模擬卜リーチャンネルからのトリ 一伸展に伴う部分放電パルス列の特性」, 電学論 $\mathrm{A}, 120,4, \mathrm{pp}$. 499-505 (2000-4)

(10) F. Komori, N. Nishiguchi, M. Hikita, and T. Mizutani : "Degradation Diagnosis and Estimation of Residual Life of Insulating Material using Pattern Recognition of Phase Angle Resolved Partial Discharge Pulse Occurrence Distribution", T. IEE Japan, Vol. 113-A, No. 8, pp. 586-593 (1993-8) (in Japanese) 古森郁尊・西口法明・匹田政幸・水谷照吉 :「部分放電発生位相角分 布によるパターン認識を応用した絶縁劣化診断および余寿命推定」, 電学論 A, 113, 8, pp. 586-593 (1993-8)

(11) H. Kaneiwa, Y. Suzuoki, and T. Mizutani : "Partial Discharge Characteristics and Tree Propagation in Artificially-Simulated Tree Channel", 6th Int. Conf. on Con. \& Break. in Sol. Diel., pp. 123-126 (1998-6)
(12) N. Hozumi, T. Okamoto, and T. Imajo : "The Influence of Space Charge on the Growth of an Initial Electrical Tree in Polyethylene", T. IEE Japan, Vol. 111-A, No. 4, pp. 341-349 (1991-4) (in Japanese)

穂積直裕・岡本達希・今城尚久:「ポリエチレン中の初期電気トリー の成長に及ぼす空間電荷の影響」, 電学論 A，111，4，pp. 341-349 (1991-4)

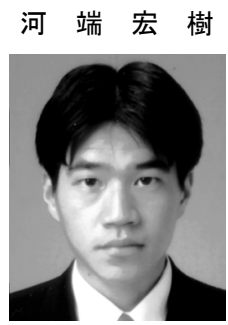

（学生員）1978 年 4 月 17 日生まれ。 2001 年 4 月名古屋大学大学院工学研究科博士課程前期 課程進学, 現在に至る。高分子絶縁材料中の電 気トリーおよび部分放電に関する研究に従事。

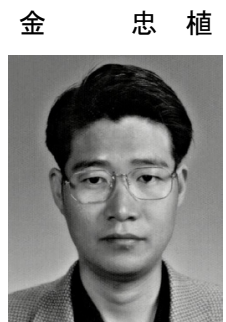

（学生員）1963 年 2 月 24 日生まれ。1988 年 2 月韓国・漢陽大学卒業。1988 年 1 月 LG 電線 入社。2002 年 4 月名古屋大学大学院工学研究 科博士課程後期課程入学, 現在に至る。高分子 絶縁材料の絶縁劣化診断, 部分放電に関する研 究に従事。

水 谷 照 吉 (正員) 1941 年 5 月 9 日生まれ。 69 年 3 月名 古屋大学大学院工学研究科博士課程修了。 69 年 4 月より名古屋大学工学部電気学科助手, 講師，助教授を経て 87 年 7 月同教授，現在に 至る。工学博士。9 97 年電気学会業績賞受賞。 主として誘電・絶縁材料, 薄膜デバイス, 有機 エレクトロニクスに関する研究に従事。 IEEE, CIGRE, 応用物理学会, 高分子学会, 放電学会会員。 